\title{
Impact Evaluation of Energy Conservation Measures Installed at Mayr Brothers Logging Company Under the Energy \$avings Plan
}

\author{
D. R. Brown \\ G. E. Spanner
}

May. 1995 Government. Neither the United States Government nor any agency thereof, nor any of their employees, makes any warranty, express or implied, or assumes any legal liability or responsibility for the accuracy, completeness, or usefulness of any information, apparatus, product, or process disclosed, or represents that its use would not infringe privately owned rights. Reference herein to any specific commercial product, process, or service by trade name, trademark, manufacturer, or otherwise does not necessarily constitute or imply its endorsement, recommendation, or favoring by the United States Government or any agency thereof. The views and opinions of authors expressed herein do not necessarily state or reflect those of the United States Government or any agency thereof.

\section{Prepared for Sheila Riewer}

Measurement and Evaluation Section

Office of Marketing, Conservation and Production

Bonneville Power Administration

U.S. Department of Energy

under Contract DE-AC06-76RLO 1830

Pacific Northwest Laboratory

Richland, Washington 99352 


\section{DISCLAIMER:}

This report was prepared as an account of work sponsored by an agency of the United States Government. Neither the United States Government nor any agency thereof, nor Battelle Memorial Institute, nor any of their employees, makes any warranty, expressed or implied, or assumes any legal liability or responsibility for the accuracy, completeness, or usefulness of any information, apparatus, product, or process disclosed, or represents that its use would not infringe privately owned rights. Reference herein to any specific commercial product, process, or service by triade name, trademark, manufacturer, or otherwise does not necessarily constitute or imply its endorsement, recommendation, or favoring by the United States Government or any agency thereof, or Battelle Memorial Institute. The views and opinions of authors expressed herein do not necessarily state or reflect those of the United States Government or any agency thereof.

\section{PACIFIC NORTHWEST LABORATORY}

operated by

BATTELLE MEMORIAL INSTITUTE

for the

UNITED STATES DEPARTMENT OF ENERGY

under Contract DE-ACO6-76RLO 1830 


\section{DISCLAIMER}

Portions of this document may be illegible in electronic image products. Images are produced from the best available original document. 


\section{Summary}

This impact evaluation of adjustable speed drives (ASDs), programmable logic controllers (PLCs), and high efficiency motors (HEMs) that were recently installed at Mayr Brothers Logging Co., Inc. (Mayr Bros.) was conducted for the Bonneville Power Administration (Bonneville) as part of an evaluation of its Energy \$avings Plan (E\$P) Program. The project consists of ASDs, PLCs, and HEMs that were installed at the Mayr Bros.' new small log mill at their facility in Hoquiam, Washington. Energy savings directly accrue through improved motor efficiency and indirectly accrue via an increase in production rate. This latter effect reduces energy consumption per unit of production by spreading fixed energy requirements over a greater number of units. The objective of this impact evaluation was to assess how much electricity is being saved at Mayr Bros. as a result of the E\$P and to determine how much the savings cost Bonneville and the region. The impact of the project was evaluated with a combination of engineering analysis, financial analysis, interviews, and submittal reviews (Mayr Bros.' proposal and completion report).

Based on this impact evaluation, energy savings from this project are expected to be $1,100,000$ kilowatt-hours/year ( $\mathrm{kWh} / \mathrm{yr}$ ) or 0.126 average megawatts (aMW). On a unit production basis, this project will save $1.45 \mathrm{kWh} / \mathrm{m}^{3}\left(0.041 \mathrm{kWh} / \mathrm{ft}^{3}\right)$ of merchandiser output, $5.08 \mathrm{kWh} / \mathrm{m}^{3}$ $\left(0.144 \mathrm{kWh} / \mathrm{ft}^{3}\right)$ of refuse system output, and $5.08 \mathrm{kWh} / \mathrm{m}^{3}(0.012 \mathrm{kWh} /$ board-foot $)$ of sawmill output. The project cost $\$ 651,099$ to install in 1992 . Mayr Bros. received payment of $\$ 695,871$ from Bonneville in 1993 for the acquisition of energy savings. The real levelized cost of these energy savings to Bonneville is 61.8 mills $/ \mathrm{kWh}$ (in 1993 dollars) over the project's assumed 15-year life, and the real levelized cost to the region is 38.0 mills $/ \mathrm{kWh}$, not including transmission and distribution effects.

The energy conservation measures were incorporated into the small log mill while the mill was constructed in 1992 and 1993. Financing the new mill had stretched Mayr Bros.' cash and credit resources to the limit. Without the acquisition payment, Mayr Bros. would not have been able to afford the additional investment in the energy conservation measures. Therefore, all of the project's impact can be attributed to the E\$P.

The key recommendation resulting from this impact evaluation is to avoid the direct comparison of energy consumption estimates derived via engineering calculations and metering. If "before and after" metering is not possible, engineering calculations should be calibrated against metered data to enhance comparability. If calibration seems imprudent, basing energy savings entirely on engineering calculations would be preferable to mixing calculations and metering. As always, care must be taken to account for the impact of changes in production conditions on energy savings.

iii

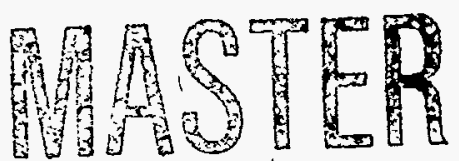




\section{Contents}

Summary $\ldots \ldots \ldots \ldots \ldots \ldots \ldots \ldots \ldots \ldots \ldots \ldots \ldots \ldots \ldots$ iii

1.0 Introduction $\quad \ldots \ldots \ldots \ldots \ldots \ldots \ldots \ldots \ldots \ldots \ldots \ldots \ldots \ldots \ldots \ldots$

1.1 Approach for Impact Evialuation $\ldots \ldots \ldots \ldots \ldots \ldots \ldots \ldots \ldots \ldots .2$

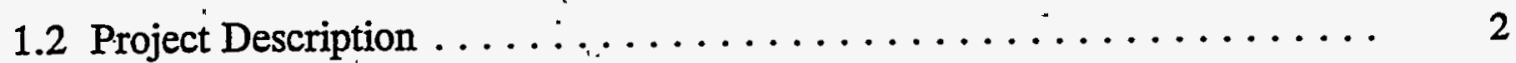

1.3 Summary of Project Impacts $\ldots \ldots \ldots \ldots \ldots \ldots \ldots \ldots \ldots \ldots \ldots$

2.0 Impact Evaluation $\ldots \ldots \ldots \ldots \ldots \ldots \ldots \ldots \ldots \ldots \ldots \ldots \ldots \ldots \ldots \ldots \ldots \ldots$

2.1 Energy Savings and Fuel Switching $\ldots \ldots \ldots \ldots \ldots \ldots \ldots \ldots \ldots \quad 5$

2.2 Impacts to the Firm $\ldots \ldots \ldots \ldots \ldots \ldots \ldots \ldots \ldots \ldots \ldots \ldots, 17$

2.3 Impacts to the Utility $\ldots \ldots \ldots \ldots \ldots \ldots \ldots \ldots \ldots \ldots \ldots \ldots$

2.4 Real Levelized Costs . . . . . . . . . . . . . . . . . 18

2.4.1 Bonneville Perspective $\ldots \ldots \ldots \ldots \ldots \ldots \ldots \ldots \ldots \ldots \ldots \quad 18$

2.4.2 Regional Perspective ................... 19

2.5 Impact Attributable to $\mathrm{E} \$ \mathrm{P} \ldots \ldots \ldots \ldots \ldots \ldots \ldots \ldots \ldots \ldots \ldots \ldots$

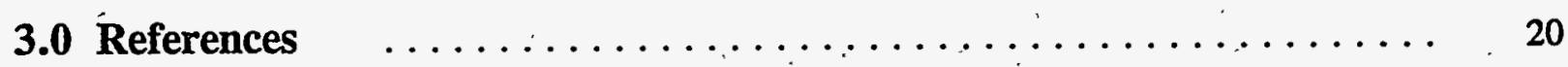

Appendix A - Financial Evaluation Details $\ldots \ldots \ldots \ldots \ldots \ldots \ldots \ldots$ A.1

Appendix B - Cover Sheet from Mayr Bros.' Proposal $\ldots \ldots \ldots \ldots \ldots$ B.1

Appendix C - Project Cost Estimates $\ldots \ldots \ldots \ldots \ldots \ldots \ldots \ldots \ldots \ldots$ C.1 


\section{Tables}

2.1 Energy Consumption Indices with ECMs Installed $: \ldots \ldots \ldots \ldots \ldots \ldots \ldots$

2.2 Merchandiser Operating Conditions $\ldots \ldots \ldots \ldots \ldots \ldots \ldots \ldots \ldots \ldots \ldots$

2.3 Merchandiser Energy Indices $\ldots \ldots \ldots \ldots \ldots \ldots \ldots \ldots \ldots \ldots \ldots$

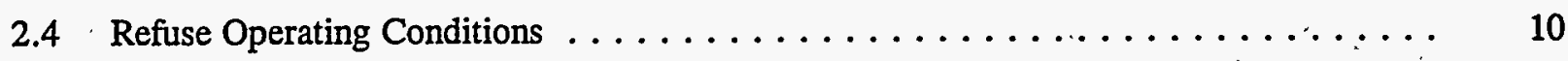

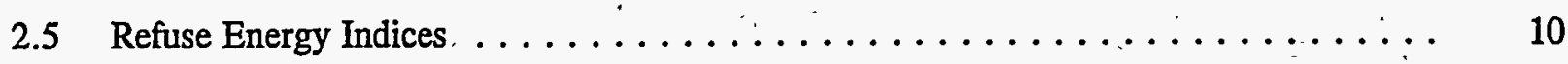

2.6 Sawmill Operating Conditions $\ldots \ldots \ldots \ldots \ldots \ldots \ldots \ldots \ldots \ldots \ldots \ldots .11$

2.7 Sawmill Energy Indices $\ldots \ldots \ldots \ldots \ldots \ldots \ldots \ldots \ldots \ldots \ldots \ldots \ldots .11$

2.8 Alternative Energy Savings Estimates $\ldots \ldots \ldots \ldots \ldots \ldots \ldots \ldots \ldots \ldots, 12$

2.9 Merchandiser Energy Savings Calculations $\ldots \ldots \ldots \ldots \ldots \ldots \ldots \ldots \ldots \ldots$

2.10 Refuse Energy Savings Calculations $\ldots \ldots \ldots \ldots \ldots \ldots \ldots \ldots \ldots \ldots$

2.11 Sawmill Energy Savings Calculations $\ldots \ldots \ldots \ldots \ldots \ldots \ldots \ldots \ldots \ldots \ldots \ldots$

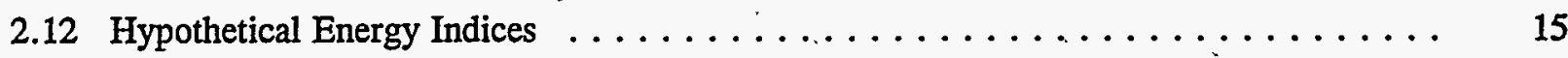




\subsection{Introduction}

This report describes Pacific Northwest Laboratory's (PNL's) ${ }^{(a)}$ evaluation of the impact of an energy conservation project completed in the fall of 1992 at Mayr Brothers Logging Co., Inc. (Mayr Bros.) in Hoquiam, Washington. The project at Mayr Bros. is one in a continuing series of industrial energy conservation projects that have received or will receive acquisition payments from the Bonneville Power-Administration (Bonneville) under the Energy \$avings Plan (E\$P) Program, and that are being evaluated by PNL:

The E\$P is designed to reduce electricity consumption in the industrial sector of Bonneville's service territory. For the Mayr Bros. project, the acquisition payment offered under the program was $25.4 \mathrm{c} /$ kilowatt-hour $(\mathrm{kWh})$ saved in the first year.

The general objective of the impact evaluation was to determine how much electricity is saved by the project and at what cost to Bonneville and to the region. In support of this general objective, answers were sought to the following questions:

1. How much electricity is saved annually by the energy conservation project in terms of kilowatt-hours, kilowatt-hours per unit of plant output (unit savings), and average megawatts (aMW)? Also, did any fuel switching result from implementing this project?

2. If the project improved the productivity of the process, did the firm then increase output of the process to take advantage of the productivity improvement? Did the change in output result in a net increase or decrease in energy used by the process? Did the change in output cause changes in output at the firm's other plants in the region?

3. What was the net impact to the serving utility in terms of electricity consumption (in kilowatthours) from implementing the project?

4. What are the real levelized costs of the project from the perspectives of Bonneville and the region?

5. How much of the project's savings can be attributed solely to the E\$P?

(a) Pacific Northwest Laboratory is operated for the U.S. Department of Energy by Battelle Memorial Institute under Contract DE-AC06-76RLO 1830. 


\subsection{Approach for Impact Evaluation}

Before selecting individual energy conservation projects for evaluation, PNL developed a general impact evaluation methodology (Spanner et al. 1988). The major finding of the methodology development wàs that in the industrial sector, energy conservation projects must be evaluated on a case-by-case basis. Accordingly, the general methodology consists of a variety of impact evaluation techniques that can be applied to individual projects according to the specific circumstances.

To evaluate the impact of installing adjustable speed drives (ASDs), programmable logic controllers (PLCs), and high efficiency motors (HEMs) at Mayr Bros.' small log mill, four techniques were selected from the general methodology: engineering analysis, financial analysis (see Appendix A), site visit and interview, and review of Mayr Bros.'.submittals. Submetering performed by Elliot Bay Engineering in accordance with E\$P program requirements was relied upon by PNL to determine the project's impact. Representatives from PNL visited Mayr Bros. on January 12, 1994 to view the project firsthand and to interview the General Manager, Mill Superintendent, and Maintenance Superintendent from Mayr Bros., and project consulting engineers from BRACO Energy Services.

\subsection{Project Description}

Mayr Bros. is in the business of producing finished lumber from logs. Chips for pulping and hog fuel for boilers are significant co-products. Facilities are typical for a lumber mill and include log yards, sawmills, chipping mills, a boiler, a lumber kiln, and miscellaneous support facilities. Market conditions suggest that the diameter of the average log will decline in the future. In response to this trend, Mayr Bros. constructed a new mill to handle the smaller-sized logs. The principal components of the small log mill are the merchandiser, refuse system, and sawmill. The merchandiser processes raw logs into merchantable logs for resale or conversion into lumber. The first step is debarking. Based on quality, a debarked log is either routed to the refuse system for chipping, or the bucksaw where it is cut to various lengths. Logs passing through the bucking operation are sorted into bins by length and diameter where they are temporarily stored. Bark is sent to the refuse system for conversion to hog fuel. In the sawmill, merchantable logs are first directed through the hewsaw, which simultaneously produces rough lumber and pulping chips. After trimming, the rough lumber is sorted and stacked, and then is sent to the kiln for drying. 
In the energy conservation project at Mayr Bros., HEMs were installed in all three parts of the small log mill, while ASDs and PLCs were installed in the merchandiser and sawmill. In general, the ASDs and PLCs work together to increase the allowable flow of logs through the merchandiser and sawmill while keeping the motors more efficiently loaded. Flux-vector ASDs were used in the merchandiser due to the high torque and precise control requirements that variable frequency ASDs cannot provide. Energy savings accrue via increased motor efficiency (combination of HEMs and more efficient motor loadings) and increased throughput, which minimizes equipment idling time and spreads fixed power requirements over a larger production base. This latter effect dominates the energy savings impact, which puts a premium on specifying the presumed production levels with and without the energy conservation measures (ECMs).

BRACO Energy Services (BRACO) and Grays Harbor Fublic Utility District (GHPUD) submitted two documents to Bonneville on Mayr Bros.' behalf: 'a proposal and a completion report. The proposal described the energy conservation project and presented cost and energy savings expectations. A completion report was submitted to Bonneville after the project was installed and energy consumption at the small log mill was metered for a two-week period. This document listed the actual costs of the project along with a calculation of the energy savings that had been achieved. A copy of the cover sheet from the proposal is included in Appendix B.

The ECMs were installed at the time the small log mill was constructed in 1992, in contrast to being installed as a retrofit. Therefore, it was not possible to meter energy consumption for the "before" condition. In addition, historical production records were not available. BRACO and GHPUD worked with Mayr Bros. prior to installing the EClMs to define expected motor loadings and production rates for the small log mill with and without the ECMs. These data were used to calculate baseline energy consumption indices ( $\mathrm{kWh}$ per unit of product) for the merchandiser, refuse, and sawmill systems. Actual energy consumption indices were calculated after the mill was constructed based on metered energy consumption and production recorded during a two-week period. Energy savings were calculated by multiplying the difference between baseline and measured energy indices by the presumed baseline production level. This verification procedure and its result (energy savings of $2,739,650 \mathrm{kWh} /$ year) were documented in the completion rejort. Several alternative verification procedures, including the one used by PNL in this impact evaluation, are presented and discussed in Section 2.0.

The total cost to install this project was estimated by PNL to be about $\$ 650,000$, and Bonneville paid $\$ 723,268$ for the energy saved. The actual cost of installing the energy conservation measures is uncertain because some judgment must be applied in determining the portion of total small log mill 
construction costs that were attributable to the energy conservation project. The.PNL estimate is lower than Bonneville's estimate $(\$ 702,848)$, which is lower than the estimate presented in the completion report $(\$ 825,511)$. An itemized listing of the three estimates is presented in Appendix C. The acquisition payment was calculated by multiplying the energy savings documented in the completion report $(2,739,650 \mathrm{kWh})$ by the acquisition rate $(25.4 \mathrm{c} / \mathrm{kWh})$.

\subsection{Summary of Project Impacts}

This E\$P project is expected to save $1,100,000 \mathrm{kWh}$ annually or $0.126 \mathrm{aMW}$. Over the assumed 15-year life of this project, the levelized cost to Bonneville is 61.8 mills $/ \mathrm{kWh}$ (1. mill $=1 / 1000$ of a dollar), and the cost to the region is $38.0 \mathrm{mills} / \mathrm{kWh}$. These costs are in real 1993 dollars and do not include additional savings that accrue if transmission and distribution losses are considered. The levelized cost to Bonneville including transmission and distribution losses is 57.5 mills $/ \mathrm{kWh}$, and the cost to the region is $35.4 \mathrm{mills} / \mathrm{kWh}$.

The energy conservation measures were incorporated into the small log mill while the mill was constructed in 1992 and 1993. Financing the new mill had stretched Mayr Bros.' cash and credit resources to the limit. Without the acquisition payment, Mayr Bros. would not have been able to afford the additional investment in the energy conservation measures. Therefore, all of the project's impact can be attributed to the E\$P. 


\subsection{Impact Evaluation}

The following section addresses the five major objectives of the impact evaluation, as previously stated in Section 1.0.

\subsection{Energy Savings and Fuel Switching}

1. How much electricity is saved annually by the project in terms of kilowatt-hours, kilowatt-hours per unit of plant output, and average megawatts? Also, did any fuel switching result from implementing this project?

\section{Energy Savings}

As previously noted, BRACO and GHPUD worked with Mayr Bros. prior to installing the ECMs to define expected motor loadings and production rates for the small log mill with and without the ECMs. These data, along with subsequent operating experience, were used by PNL to develop energy models for merchandiser, refuse, and sawmill systems. In turn, the models were used to predict energy consumption at alternative production rates and operating schedules, which significantly impact mill energy productivity. Specifically, the models were used to predict energy consumption for conditions presumed prior to construction (baseline and estimated ECM operating scenarios), average conditions during the two-week metering period (metered ECM operating scenario), and average conditions from January through May, 1994 (long-run operating scenario).

Given the energy models, calculation of energy savings can proceed down several alternative paths, which vary depending on the perspective taken. Energy savings were estimated by BRACO by subtracting the measured energy indices with the ECMs from the estimated energy indices for the baseline system and multiplying these differences (for merchandiser, refuse, and sawmill systems) by the estimated baseline production. This approach to calculating energy savings is summarized by Equation (1). Alternative calculational approaches are presented in Equations (2) through (6). An energy index refers to the number of kilowatt-hours consumed per unit of production. "Baseline" refers to the conditions presumed to exist if the ECMs had not been installed and "ECM" refers to conditions with the ECMs installed.

$$
\text { Energy Savings }=(\mathrm{A}-\mathrm{B}) * \mathrm{D}
$$




$$
\begin{aligned}
& \text { Energy Savings }=(\mathrm{A}-\mathrm{C}) * \mathrm{D} \\
& \text { Energy Savings }=(\mathrm{A}-\mathrm{B}) * \mathrm{E} \\
& \text { Energy Savings }=(\mathrm{A}-\mathrm{C}) * \mathrm{E} \\
& \text { Energy Savings }=(\mathrm{A} * \mathrm{D})-(\mathrm{B} * \mathrm{E}) \\
& \qquad \begin{array}{r}
\vdots \\
\text { Energy Savings }=(\mathrm{A} * \mathrm{D})-(\mathrm{C} * \mathrm{~F}) \\
\text { Where } \mathrm{A}=\text { estimated baseline energy index, } \\
\mathrm{B}=\text { measured } \mathrm{ECM} \text { energy index, } \\
\mathrm{C}=\text { estimated } \mathrm{ECM} \text { energy index, } \\
\mathrm{D}=\text { estimated baseline production, } \\
\mathrm{E}=\text { measured } \mathrm{ECM} \text { production, and } \\
\mathrm{F}=\text { estimated } \mathrm{ECM} \text { production. }
\end{array}
\end{aligned}
$$

The approaches in Equations (1) through (4) focus on the change in unit energy consumption or energy productivity while the approaches in Equations (5) and (6) focus on the change in total energy consumption. Equations (5) and (6) are relevant to determining the actual change in kilowatt-hour consumption at the mill and the corresponding impact on the serving utility. Note that total energy consumption will increase if the percentage increase in production is greater than the percentage decrease in the energy index.

Simply decreasing total energy consumption is not a sufficient objective for energy conservation programs in general, or the E\$P in particular. Improvement in energy productivity is suggested as a more effective objective. Even if total industry production increases, energy productivity improvements effectively save energy, compared to what energy consumption would have been if ECMs were not implemented. Thus, a focus on energy productivity is appropriate from a regional perspective, while focusing on total energy consumption at the mill is appropriate from the perspective of the serving utility.

Equations (3) and (4) assume the energy productivity-improvement applies to the new production level while Equations (1) and (2) assume the improvement only applies to the baseline production level. Implicitly, Equations (3) and (4) assume that without the ECMs, the new production would have occurred somewhere at the baseline productivity level. With at least two other small log mills in the 
Pacific Northwest employing conventional control technologies, this assumption seems reasonable. Conversely, Equations (1) and (2) implicitly assume that any incremental production associated with the ECM would have occurred somewhere else at the new productivity level. If all other small log mills were already employing the more efficient control strategy installed at Mayr Bros., then Equation (1) or (2) would be preferred.

Equations (1), (3), and (5) are based on measured energy consumption with the ECMs, while Equations (2), (4), and (6) rely on estimated energy consumption with the ECMs. All equations are based on estimated energy consumption for the baseline system because the baseline small log mill only existed on paper. In addition, Equations (1) through (6) are based on the reduction in energy consumption between the baseline and ECM systems. Therefore, absolute accuracy of ECM or baseline energy consumption is not as important as the relative accuracy of the two figures; the focus is on the difference between the two figures. Using two different approaches (e.g., estimated vs. measured) for calculating energy consumption will almost always result in different values. The different values reported in the proposal and completion report (and reproduced in Table 2.1) for energy consumption indices with the ECMs installed illustrates the problem. The energy models developed by PNL were used to estimate energy indices with and without the ECMs. Energy consumption estimated with the ECMs can be directly compared to measured energy consumption with the ECMs to judge the accuracy of the model. Although measurement (metering) produces a more accurate assessment of the energy consumption indices, the differences in measured and estimated (engineering calculation) values, with the ECMs installed, casts doubt on the accuracy of the estimated values for the baseline system. Therefore, some adjustment of the baseline indices (based on the knowledge of measured and estimated indices with the ECMs installed) is suggested.

Table 2.1. Energy Consumption Indices with ECMs Installed

\begin{tabular}{|l|c|c|}
\hline \multicolumn{1}{|c|}{ System } & Estimated & Measured \\
\hline Merchandiser & 0.1358 & 0.1495 \\
Refuse & 0.8156 & 0.5011 \\
Sawmill & 0.0552 & 0.0294 \\
\hline
\end{tabular}


One possible adjustment mechanism is that defined by Equation (7). The difference found between measured and estimated ECM indices is presumed to proportionally apply to baseline indices. This approach was considered and rejected by Bonneville because an increase in measured ECM indices translates into an increase in the energy savings estimate, which runs counter to the intuitive relationship. However, the adjustment must be considered from the viewpoint that if the estimated ECM index is too low, then the estimated baseline index may also be too low. The applicability of Equation 7 depends on whether factors affecting the ratio of measured and estimated ECM indices also apply to the baseline system. In general, it should be easier to estimate energy consumption for conventional (baseline) technologies than for more advanced (ECM) technologies where there is less experience. Thus, inaccurate energy consumption estimates for advanced technologies do not always imply inaccurate estimates for conventional technologies. For Mayr Bros., the ratio of measured to estimated energy consumption indices with the ECMs installed was $0.614(0.5011 / 0.8156$; see Table 2.1) for the refuse system, where the only ECMs installed were a few high-efficiency motors. The inability to accurately estimate energy consumption for the refuse system cannot be attributed to inexperience with the technology. Therefore, a broader modeling problem affecting the before and after estimation of energy consumption for all three mill systems was suspected and equation 7 was judged to be applicable. The adjusted baseline index calculated from Equation ( 7 ) can be substituted for the estimated baseline enrgy index in Equations (1), (3), and (5), where estimated and measured indices are mixed.

Adjusted baseline index $=$ estimated baseline index $\bullet$ (measured ECM

$$
\text { index/estimated ECM index) }
$$

Merchandiser operating conditions and energy indices are summarized in Tables 2.2 and 2.3. The data identify the strong relationship between the production rate and energy productivity. Doubling the flow rate from the baseline operating scenario causes the energy index to drop nearly in half. Unfortunately, the average production rate recorded since the metering period was lower than the rate during the metering period or the rate predicted in the proposal. At this long-run production rate, energy consumption is only moderately lower than the baseline operating scenario. 
Table 2.2. Merchandiser Operating Conditions

\begin{tabular}{||l|c|c|c|c||}
\hline \hline Operating Scenario & Gross hr/Day & Net hr/Day & $\mathrm{m}^{3} / \mathrm{Net} \mathrm{hr}$ & $\mathrm{ft}^{3} / \mathrm{Net} \mathrm{hr}$ \\
\hline Baseline & 16 & 13.5 & 48.9 & 1,726 \\
Estimated ECM & 10.5 & 8.5 & 108.4 & 3,829 \\
Metered ECM & 10.5 & 10.0 & 73.0 & 2,578 \\
Long-Run ECM & 15.7 & 12.9 & 62.1 & 2,193 \\
\hline
\end{tabular}

Table 2.3. Merchandiser Energy Indices

\begin{tabular}{||l|c|c|c|c|c||}
\hline \multicolumn{1}{|c|}{ Operating Scenario } & $\mathrm{m}^{3} / \mathrm{day}$ & $\mathrm{ft}^{3} /$ day & $\mathrm{kWh} / \mathrm{day}$ & $\mathrm{kWh} / \mathrm{m}^{3}$ & $\mathrm{kWh} / \mathrm{ft}^{3}$ \\
\hline Baseline (estimated $\mathrm{kWh}$ ) & 660.0 & 23,306 & 5,884 & 8.90 & 0.252 \\
Estimated ECM (estimated $\mathrm{kWh}$ ) & 922.1 & 32,558 & 4,524 & 4.91 & 0.139 \\
Metered ECM (actual $\mathrm{kWh}$ ) & 730.1 & 25,781 & 3,834 & 5.26 & 0.149 \\
Metered ECM (estimated $\mathrm{kWh})$ & 730.1 & 25,781 & 4,413 & 6.04 & 0.171 \\
Long-Run ECM (estimated $\mathrm{kWh})$ & 801.1 & 28,290 & 5,770 & 7.20 & 0.204 \\
\hline \hline
\end{tabular}

Refuse operating conditions and energy indices are summarized in Tables 2.4 and 2.5. The data identify the strong relationship between the production rate and energy productivity. Doubling the . flow rate from the baseline operating scenario causes the energy index to drop in half. Unfortunately, the average production rate recorded since the metering period was lower than the rate during the metering period or predicted in the proposal.' At this long-run production rate, energy consumption is only moderately lower than the baseline operating scenario. Note that except for three small HEMs, no ECMs were installed in the refuse system, so energy procluctivity is almost entirely improved by spreading fixed energy consumption over increased throughput.

(a) PNL models developed from motor hp ratings, loadings, and operating hours presented in the proposal were used to predict the "estimated $\mathrm{kWh}$ " figures based on the alternative production conditions for each operating scenario. 
Table 2.4. Refuse Operating Conditions

\begin{tabular}{|l|c|c|c|c|}
\hline Operating Scenario & Gross hr/Day & Net hr/Day & $\mathrm{m}^{3} / \mathrm{Net} h r$ & $\mathrm{ft}^{3} / \mathrm{Net} h r$ \\
\hline Baseline & 16.5 & 13.5 & 14.1 & 497 \\
Estimated ECM & 10.5 & 8.5 & 31.2 & 1,102 \\
Metered ECM & 13.5 & 11.0 & 19.1 & 675 \\
Long-Run ECM & 15.7 & 12.9 & 17.9 & 632 \\
\hline
\end{tabular}

Table 2.5. Refuse Energy Indices

\begin{tabular}{||l|c|c|c|c|c||}
\hline \multicolumn{1}{|c|}{ Operating Scenario } & $\mathrm{m}^{3} /$ day & $\mathrm{ft}^{3} /$ Day & $\mathrm{kWh} /$ Day & $\mathrm{kWh} / \mathrm{m}^{3}$ & $\mathrm{kWh} / \mathrm{ft}^{3}$ \\
\hline Baseline (estimated $\mathrm{kWh}$ ) & 189.9 & 6,704 & 11,690 & 61.6 & 1.744 \\
Estimated ECM (estimated $\mathrm{kWh}$ ) & 265.3 & 9,366 & 7,510 & 28.3 & 0.802 \\
Metered ECM (actual $\mathrm{kWh})$ & 210.3 & 7,425 & 3,708 & 17.7 & 0.500 \\
Metered ECM (estimated $\mathrm{kWh})$ & 210.3 & 7,425 & 9,590 & 45.6 & 1.292 \\
Long-Run ECM (estimated $\mathrm{kWh})$ & 230.9 & 8,153 & 11,155 & 48.3 & 1.368 \\
\hline
\end{tabular}

Sawmill operating conditions and energy indices are summarized in Tables 2.6 and 2.7. Again, the data identify the strong relationship between production rate and energy productivity. Increasing the flow rate from the baseline operating scenario by $20 \%$ causes the energy index to drop by about $15 \%$. In contrast to merchandiser and refuse production, the average sawmill production rate recorded since the metering period was much higher than the rate during the metering period or predicted in the proposal. At this long-run production rate, energy consumption is significantly lower than for the baseline operating scenario.

(a) PNL models developed from motor hp ratings, loadings, and operating hours presented in the proposal were used to predict the "estimated $\mathrm{kWh}$ " figures based on the alternative production conditions for each operating scenario. 
Table 2.6. Sawmill Operating Condịtions

\begin{tabular}{||l|c|c|c|c||}
\hline Operating Scenario & Gross hr/Day & Net hr/Day & $\mathrm{m}^{3} / \mathrm{Net} \mathrm{hr}$ & Board-Feet/Net hr \\
\hline Baseline & 10.5 & 8.5 & 22.20 & 9,408 \\
Estimated ECM & 10.5 & 8.5 & 26.64 & 11,290 \\
Metered ECM & 10.5 & 10.0 & 358.99 & 12,676 \\
Long-Run ECM & 13.2 & 10.79 & 40.21 & 17,040 \\
\hline
\end{tabular}

Table 2.7. Sawmill Energy Indices

\begin{tabular}{||l|c|c|c|c|c||}
\hline Operating Scenario & $\mathrm{m}^{3} /$ day & Board-Feet/Day & $\mathrm{kWh} /$ Day & $\mathrm{kWh} / \mathrm{m}^{3}$ & $\mathrm{kWh} /$ Board-Foot \\
\hline $\begin{array}{l}\text { Baseline (estimated } \\
\mathrm{kWh})^{(\mathrm{a})}\end{array}$ & 188.71 & 79,968 & 4,430 & 23.48 & 0.0554 \\
Estimated ECM \\
(estimated $\mathrm{kWh}$ )
\end{tabular}

The results of applying the operating conditions and energy indices specified in Tables 2.2 through 2.7 to Equations (1) through (T) are shown in Table 2.8. The figures demonstrate the wide variation in estimated energy savings possible, depending on the estimating method chosen. The variation is pronounced for the refuse system because of large differences between estimated and actual energy consumption, which amplifies the need to adjust the estimated baseline energy indices if they are to be

(a) PNL models developed from motor hp ratings, loadings, and operating hours presented in the proposal were used to predict the "estimated $\mathrm{kWh}$ " figures based on the alternative production. conditions for each operating scenario. 
used with measured ECM indices. Equation (6) or the combination of Equations (5) and (7) estimate an increase in sawmill energy consumption because production increases by a greater percentage than the percentage decrease in the energy index.

Table 2.8. Alternative Energy Savings Estimates

\begin{tabular}{|c|c|c|c|c||}
\hline $\begin{array}{c}\text { Energy } \\
\text { Savings } \\
\text { Equation(s) }\end{array}$ & $\begin{array}{c}\text { Merchandiser } \\
\text { Energy Savings } \\
(\mathrm{kWh})\end{array}$ & $\begin{array}{c}\text { Refuse System } \\
\text { Energy Savings } \\
(\mathrm{kWh})\end{array}$ & $\begin{array}{c}\text { Sawmill Energy } \\
\text { Savings (kWh) }\end{array}$ & $\begin{array}{c}\text { Total Energy } \\
\text { Savings (kWh) }\end{array}$ \\
\hline$(1)$ & 577,697 & $2,003,113$ & 487,273 & $3,068,803$ \\
$(2)$ & 453,905 & 730,064 & 238,021 & $1,421,990$ \\
$(3)$ & 639,057 & $2,218,267$ & 772,421 & $3,629,745$ \\
$(4)$ & 502,116 & 808,480 & 377,308 & $1,687,904$ \\
$(5)$ & 489,029 & $1,916,365$ & 178,870 & $2,584,264$ \\
$(6)$ & 352,089 & 506,578 & $(216,243)$ & 642,424 \\
$(1) \&(7)$ & 395,288 & 283,380 & 161,595 & 840,263 \\
$(3) \&(7)$ & 437,273 & 313,818 & 256,158 & $1,007,249$ \\
$(5) \&(7)$ & 306,620 & 196,632 & $(146,809)$ & 356,443 \\
\hline
\end{tabular}

Energy savings calculations at the small $\log$ mill were further complicated by the fact that production during the metering period was not representative of conditions expected in the long run. This required an additional adjustment to the ECM energy index that was calculated via Equation (8). The ratio of measured energy index to estimated energy index for the metered ECM scenario was used to calculate adjusted baseline and long-run ECM energy indices via Equations (7) and (8), respectively. The difference between these two indices was multiplied by the projected annual production to estimate energy savings via Equation (3). Long-run annual production was extrapolated from actual production from January through May, 1994. The energy savings estimating methods and results are summarized in Tables $2.9,2.10$, and 2.11 .

$$
\begin{aligned}
& \text { Adjusted long-run ECM index = estimated long-run ECM index } \bullet \text { (measured ECM } \\
& \text { index/estimated ECM index) }
\end{aligned}
$$


Table 2.9. Merchandiser Energy Savings Calculations

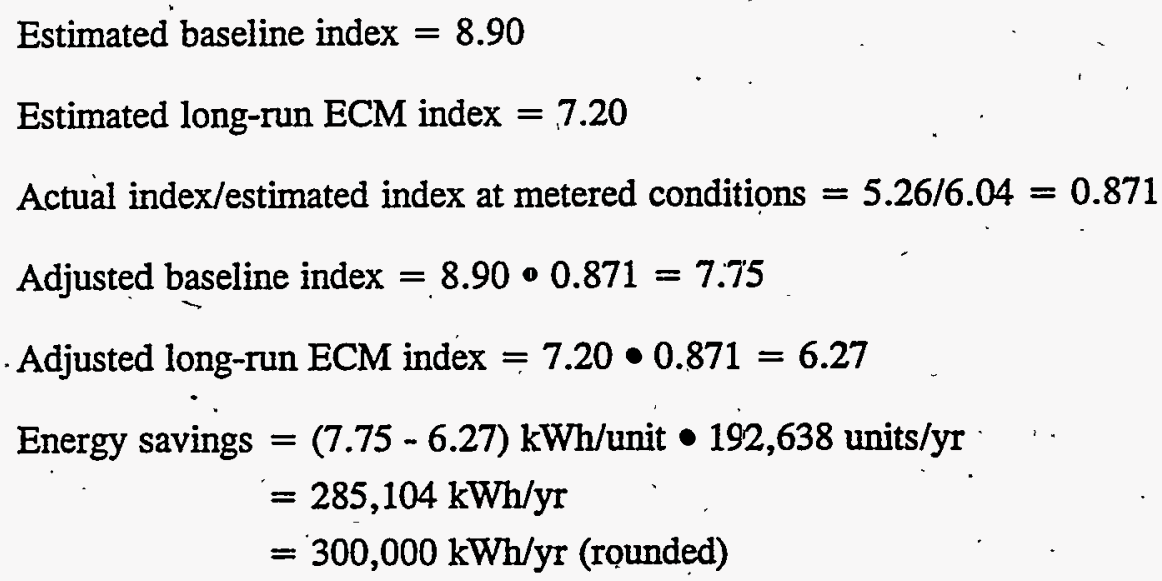

Energy savings in completion report $=430,407 \mathrm{kWh} / \mathrm{yr}$

Table 2.10. Refuse Energy Savings Calculations

Estimated baseline index $=61.6$

Estimated long-run ECM index $=48.3^{\circ}$

Actual index/estimated index at metered conditions $=17.7 / 45.6=0.388$

Adjusted baseline index $=61.6 \cdot 0.388=23.9$

Adjusted long-run ECM index $=48.3 \bullet 0.388=18.7$

Energy savings $=(23.9-18.7) \mathrm{kWh} /$ unit $\bullet 55,480$ units/yr

$$
\begin{aligned}
& =288,496 \mathrm{kWh} / \mathrm{yr} \\
& =300,000 \mathrm{kWh} / \mathrm{yr} \text { (rounded) }
\end{aligned}
$$

Energy savings in completion report $=1,757,368 \mathrm{kWh} / \mathrm{yr}$ 
Table 2.11. Sawmill Energy Savings Calculations

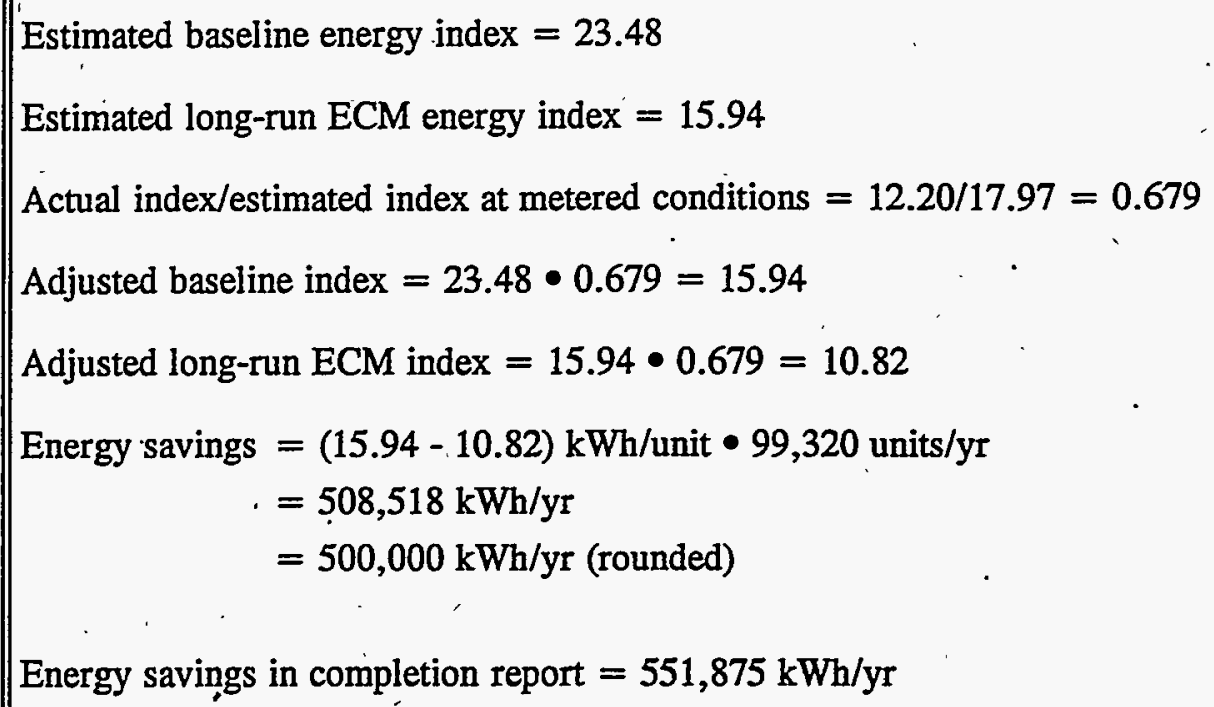

As the data presented in Tables 2.2 through 2.11 indicate, the presumed production rates have a profound effect on the energy consumption indices and energy savings. Based on the average production rates recorded from January through May, 1994 energy savings were estimated by PNL to be about $1,100,000 \mathrm{kWh}$ per year or $0.126 \mathrm{aMW}$. Production rates during the metering period were higher for the merchandiser and refuse systems, but lower for the sawmill. If the metering period production rates are presumed for the long run, energy savings are estimated by PNL to be about $1,000,000 \mathrm{kWh} /$ year. These two energy savings estimates are still significantly lower than the energy savings estimated in the proposal $(1,800,000 \mathrm{kWh})$ or completion report $(2,700,000 \mathrm{kWh})$. Based on the production rates presumed in the proposal (which were higher for merchandiser and refuse systems, but lower for the sawmill compared to production rates during the metering period), energy savings were estimated by PNL to be about $1,700,000 \mathrm{kWh} /$ year. ${ }^{(a)}$ Increasing the production rate takes advantage of equipment consuming a fixed amount of energy to lower the average energy consumption per unit of product.

(a) Although PNL and proposal estimates of energy savings for proposal production rates are close, the components of the estimates are quite different. For example, the PNL estimate is based on the projected ECM production rates which are $40 \%$ higher than the baseline merchandiser and refuse system production rates assumed in the proposal calculation of energy savings. The production rate difference is offset by differences in the energy indices. 
The data presented in Tables $2.9,2.10$, and 2.11 also show that the metered energy consumption was always lower than the estimated energy consumption at the same production rate and operating hour conditions. Specifically, the ratio of metered energy consumption to estimated energy consumption was $0.871,0.388$, and 0.679 for merchandiser, refúse, and sawmill systems, respectively. The estimating equations were derived from motor ratings and loading assumptions presented in the proposal, which directly implies that the loading assumptions were too high for the ECM case. This also implies that motor loadings were too high for the baseline case because the majority of the energy savings are attributable to spreading fixed loads (e.g., the refuse system) over a higher throughput rather than directly reducing energy consumption at the same throughput (e.g., via HEMs and more efficient loading of debarker and hewmill motors). Therefore, some adjustment of the baseline energy consumption indices is justified to obtain a reasonably accurate estimate of energy savings.

The differences in PNL, proposal, and completion report energy indices, and the impact on the energy savings estimated can be illustrated by the following example, which is similar, but not exactly the same as the conditions at Mayr Bros. Presume that the ICMs reduce the energy index by half from the baseline system, but the measured index is only half the estimated index for the ECM system. Baseline and ECM indices and energy savings are presented in Table 2.12 based on the calculational procedures used in the proposal, completion report, and this impact evaluation. Energy savings estimated in the completion report are higher than estimated in the proposal because the baseline index was not adjusted. Adjusting the baseline index based on the knowledge of metered and estimated ECM indices results in a lower and more accurate estimate of energy savings.

Table 2.12. Hypothetical Energy Indices

\begin{tabular}{|l|c|c|c|}
\hline \multicolumn{1}{|c|}{ Reference } & Baseline & ECM & Savings \\
\hline Proposal & 4 & 2 & 2 \\
Completion Report & 4 & 1 & 3 \\
Impact Evaluation & 2 & 1 & 1 \\
\hline
\end{tabular}




\section{Energy Savings Summary and Recommendations}

Estimating the energy savings at the Mayr Bros. small log mill was complicated by the inability to meter energy consumption for the baseline system. The baseline system never physically existed and it was impossible to simply "turn off" the ECMs and meter energy consumption after the mill was constructed. Therefore, engineering calculations were required to estimate baseline energy consumption. Metering established actual energy consumption with the ECMs, which differed significantly from energy consumption estimated with the ECMs via engineering calculations. However, no adjustment was made to the baseline energy consumption estimate in the completion report. Additional evaluation problems stem from uncertainty in future production rates, which strongly affect the energy savings. The PNL assessment of energy savings is significantly lower than the savings presented in the proposal or the completion report. Key differences in the analytical approach are as follows.

1. The predicted baseline energy consumption indices were adjusted by the ratio of metered to estimated ECM energy consumption (see Equation 7). This has the effect of decreasing the savings estimate. .

2. The ECM energy consumption indices were adjusted to reflect average production rates and operating schedules from January through May, 1994 rather than the conditions existing during the two-week metering period. This had the effect of decreasing the savings estimate for the merchandiser and refuse systems while increasing the savings estimate for the sawmill.

3. The difference between baseline and ECM energy indices was multiplied by the expected future production rate rather than the presumed baseline production rate (see Equation 3). This has the effect of increasing the savings estimate.

The key recommendation resulting from this impact evaluation is to avoid the direct comparison of energy consumption estimates derived via engineering calculations and metering. If "before and after" metering is not possible, engineering calculations should be calibrated against metered data to enhance comparability. Thus, Equations (1), (3), or (5), used in combination with Equation (7), and Equation (8) if applicable, are recommended. The specific combination recommended depends on whether a local or regional perspective is taken and implicit assumptions regarding the energy efficiency of other similar facilities in the region. If calibration seems imprudent, basing energy savings entirely on engineering calculations (Equations [2], [4], or [6]) would be preferred to mixing calculations and metering. For the Mayr Bros. project, Equation (3), used in combination with Equations (7) and (8), 
was judged by PNL to provide the best estimate of energy savings from the perspective of Bonneville and the E\$P. As always, care must be taken to account for the impact of changes in production conditions on energy savings.

\section{Fuel Switching}

The small log mill motors require electricity to operate. Therefore, no fuel switching occurred.

\subsection{Impacts to the Firm}

2. If the project improved the productivity of the process, did the firm then increase output of the process to take advantage of the productivity improvement? Did the change in output result in a net increase or decrease in energy used by the process? Did the change in output cause changes in output at the firm's other plants in the region?

The principal benefit of this project was to increase the allowable production rate compared to what would have been achievable with conventional motor control equipment. Although some energy savings accrue through the use of HEMs and more efficient loading of debarker and hewmill motors, the greatest improvement in energy productivity is derived by spreading fixed energy consumption over higher output. Greater utilization of the total investment in the small log mill and more effective use of operating labor are additional economic benefits: The changes in production and energy consumption were measured against a presumed baseline because the mill did not exist prior to installation of the ECMs. Relative to this baseline, merchandiser and refuse system production increased by about $20 \%$, while sawmill production more than doubled. The net impact: on energy consumption was estimated to be an increase of about $250,000 \mathrm{kWh} /$ year or $8 \%$ of the estimated baseline consumption. Mayr Bros. has no other mills in the region.

\subsection{Impacts to the Utility}

3. What is the net impact to the serving utility in terms of electricity consumption (in kilowatt-hours) from implementing the project?

The energy savings estimate documented in Section 2.1 (1,100,000 kWh/year) was calculated from a regional perspective. Increased production at the mill's improved efficiency was assumed to 
otherwise have been produced in the region at the lower baseline efficiency. From the perspective of the mill and the serving utility (GHPUD), increased production more than offsets the energy efficiency improvement, resulting in a net increase of $250,000 \mathrm{kWh} /$ year relative to the presumed baseline system. Mayr Bros. does not cogenerate any power, so the $250,000 \mathrm{kWh} /$ year increase will be the impact on the serving utility.

\subsection{Real Levelized Costs}

\section{What are the real levelized costs of the project from the perspectives of Bonneville and the region?}

Real levelized annual costs are used to compare the attractiveness of various projects or investment alternatives. The levelized cost is the annual cost that would be incurred over the life of a project,: accounting for the time value of money (see Appendix A for complete definitions and formula). Levelized costs provide a single figure of merit for comparing energy conservation alternatives. In addition, levelized costs can be used to compare conservation projects with options for new generating capacity and to optimize the ranking of these options. Levelized costs are calculated from the perspectives of Bonneville and the region (Bonneville, GHPUD, and Mayr Bros. combined).

In the industrial sector, it is not possible to accurately predict the life of a project because any number of external factors could cause the project to have longer or shorter life than expected when it is installed. To allow comparisons of levelized costs among projects installed under the E\$P, all projects are assumed by PNL (for evaluation purposes) to have a life of 15 years. Even though some projects will have longer or shorter lives, 15 years is considered a conservative, but likely, life for typical projects in the industrial sector.

\subsubsection{Bonneville Perspective}

To determine the real levelized costs to Bonneville and to the region, the project costs (acquisition payment, capital costs, etc.) and energy savings must be known, and a discount rate and project life must be assumed. With energy savings of $1,100,000 \mathrm{kWh} / \mathrm{yr}$, the project's levelized cost from Bonneville's perspective is 61.8 mills $/ \mathrm{kWh}$ (in 1993 dollars, see Appendix A). Bonneville's levelized cost decreases to $57.5 \mathrm{mills} / \mathrm{kWh}$ when transmission and distribution lósses are considered. Including these losses allows for the comparison of conservation resources with generation, which is measured at the point of production rather than at the site of the end user (point of delivery). 
The levelized costs calculated in this impact evaluation include the acquisition payment by Bonneville as well as the estimated administrative and evaluation costs associated with this project.

\subsubsection{Regional Perspective}

To calculate the real levelized cost to the region; the costs to Bonneville', GHPUD, and Mayr Bros. are combined. The acquisition payment by Bonneville is included as a cost to Bonneville and as a reduction in cost to Mayr Bros. This approach is taken because the acquisition payment usually has federal income tax consequences for the company and, therefore, is not a net zero-cost to the region. In this particular case, the effective marginal income tax rate for.Mayr Bros. is expected to be zero for the next few years due to carry-over of recent operating losses. GHPUD's costs include paying for the preparation of program submittals and metering.

The calculated, real levelized cost to the region for acquiring annual energy savings of $1,100,000 \mathrm{kWh}$ is $38.0 \mathrm{mills} / \mathrm{kWh}$ saved. Including transmission and distribution losses, the levelized cost decreases to 35.4 mills $/ \mathrm{kWh}$ saved. Note that the regional levelized cost is less than Bonneville's levelized cost, implying a negative levelized cost for Mayr Bros. and GHPUD. This result is attributable to an acquisition payment that exceeded the estimated cost of the project and Mayr Bros.' peculiar tax situation.

\subsection{Impact Attributable to E\$P}

\section{How much of the project's impact can be attributed to the E\$P?}

The principal impact of the project is to allow an increase in the production rate relative to what would have been possible with conventional motor controls. While some energy savings accrue through the use of HEMs and more efficient motor loadings, the greatest efficiency improvement is derived from spreading fixed energy consumption over an increased output. Présumably, economic benefits are derived not only from increased energy productivity, but from greater utilization of capital equipment and more effective use of operating labor as well.

Unfortunately, Mayr Bros. was suffering from limited financial resources. The energy conservation measures were incorporated into the small log mill while the mill was constructed in 1992 and 1993. Financing the new mill had stretched Mayr Bros.' cash and credit resources to the limit. Without the acquisition payment, Mayr Bros. would not have been able to afford the additional investment in the energy conservation measures, regardless of the benefits noted above. Therefore, all of the project's impact can be attributed to the E\$P. 


\subsection{References}

Spanner, G. E., D. R. Brown, D. R. Dixon, B. A. Garrett, R. W. Reilly, J. M. Roop, and

S. A. Weakley. 1988. Potential Techniques for Evaluating the Impact of Industrial Energy Conservation Projects under Bonneville's Energy \$avings Plan. Letter Report. PNL-6628, Pacific Northwest Laboratory, Richland, Washington. 
Appendix A

Financial Evaluation Details 


\section{Appendix A}

\section{Financial Evaluation Details}

\section{A.1 Definitions}

- Real Levelized Cost - A single figure of merit that expresses the cost per unit of benefit (in this case, energy savings), accounting for the time value of money. This annualized cost (not the "adjusted system real levelized cost") would be constant over the entire project life. An infinite number of cash flow scenarios '(costs incurred at different times in the project life) could result in the same annualized cost.

Real Levelized Cost to Bonneville Power Administration (Bonneville) - The annualized costs to Bonneville, direct and indirect, per unit of energy saved by the energy conservation project. Costs included are the acquisition payment and the program administrative costs, as well as the costs to evaluate the impact of this project.

Real Levelized Cost to the Region - The sum of annualized costs to Bonneville, GHPUD, and Mayr Bros. per unit of energy saved by the energy conservation project. This would include the same costs to Bonneville as listed above, as well as the initial capital and ongoing incremental production costs to the firm. Any non-electrical savings that result from the project are not considered in this analysis.

\section{A.2 Real Levelized Cost Formula}

$$
\begin{gathered}
\mathrm{LC}=\{\mathrm{PVCI}+\mathrm{PVICI}+(\mathrm{PVOM}+\mathrm{PVOTE}) \bullet(1-\mathrm{itf})-\mathrm{PVD} \bullet \mathrm{itf}] \\
/(1-\mathrm{itf})\} \bullet(\mathrm{CRF} / \mathrm{AES})
\end{gathered}
$$

$$
\begin{aligned}
\text { where } \mathrm{LC} & =\text { levelized cost (real } \$ \text { ) } \\
\text { PVCI } & =\text { present value of initial capital costs } \\
\text { PVICI } & =\text { present value of interim capital costs } \\
\text { PVOM } & =\text { present value of operating and maintenance costs } \\
\text { PVOTE } & =\text { present value of one-time expenses } \\
\text { itf } & =\text { combined state and federal income tax fraction }
\end{aligned}
$$


PVD $=$ present value of depreciation

$\mathrm{CRF}=$ capital recovery factor (spreads the costs over the project life in real-dollar terms)

$\mathrm{AES}=$ annual energy savings $(\mathrm{kWh} / \mathrm{yr})$.

\section{A.3 General Assumptions}

The following general assumptions were made in the real levelized cost calculations:

1. All cash flows are expressed in nominal terms (with inflation) and are discounted to present value at a nominal discount rate of $7.12 \%$ (combines a real discount rate of $3.0 \%$ and an inflation rate of $4.0 \%$ ). The costs are annualized over the life of the project using the capital recovery factor at a real discount rate of $3.0 \%$, resulting in real levelized costs.

2. Annual energy savings $(\mathrm{kWh} / \mathrm{yr})$ are constant over the 15 -year life of the project: This assumes no loss in efficiency of the equipment with time.

3. Transmission and distribution losses equal $7.5 \%$, increasing the energy savings at the source (point of generation) by a corresponding $7.5 \%$.

4. In the regional cost calculation, the acquisition payment from Bonneville is treated as a cost to Bonneville and, at the same time, a cash inflow to Mayr Bros. rather than a net-zero cost. This is done because Mayr Bros. will incur a tax liability from the acquisition payment, thus incurring a net cost to the region.

\section{A.4 Bonneville Réal Levelized Cost Calculations}

Input:

Acquisition payment paid

Administrative and evaluation costs

Tax rate

Annual energy savings

Output:

Levelized cost

$$
\begin{aligned}
= & \$ 723,268(\mathrm{mix} \text { of } 1992 \$ \text { and } 1993 \$) \\
= & \$ 89,327(\mathrm{mix} \text { of } 1992 \$ \text { and } 1993 \$) \\
= & 0 \% \\
= & 1,100,000 \mathrm{kWh} \\
& =61.8 \mathrm{mills} / \mathrm{kWh}(1993 \$)
\end{aligned}
$$




\section{A.5 Regional Real Levelized Cost Calculations (Bonneville + Utility + Mayr Bros.)}

A. Mayr Bros. and GHPUD

Input:

Equipment purchase and installation $=\$ 547,574(1992 \$)$

Engineering, reporting, and metering $=\$ 103,525$ (1992\$)

Acquisition payment received $\quad=\$ 723,268$ ( $\operatorname{mix}$ of $1992 \$$ and $1993 \$$ )

Tax rate years $1-4)$

$=0$.

(years 5-15)

$=34 \%$

Depreciation life

$=7$ years

Annual energy savings .

$=1,100,000 \mathrm{kWh}$

Output:

Levelized cost

$=-23.8$ mills $/ \mathrm{kWh}(1993 \$)$

B. Regional levelized cost $=$ Bonneville levelized cost +

Mayr Bros. and GHPUD levelized cost

$$
\begin{aligned}
& =61.8 \text { mills } / \mathrm{kWh}+-23.8 \mathrm{mills} / \mathrm{kWh} \\
& =38.0 \text { mills } / \mathrm{kWh}(1993 \$)
\end{aligned}
$$

\section{A.6 Real Levelized Costs Allowing for Transmission and Distribution Losses}

Transmission and distribution losses $=\mathbf{7 . 5 \%}$

Bonneville levelized cost $=61.8$ mills $/ \mathrm{kWh} / 1.075=57.5 \mathrm{mills} / \mathrm{kWh}(1993 \$)$

Regional levelized cost $=38.0$ mills $/ \mathrm{kWh} / 1.075=35.4 \mathrm{mills} / \mathrm{kWh}(1993 \$)$ 
Appendix B

Cover Sheet from Mayr Bros.' Proposal 


\section{Appendix B}

\section{Cover Sheet from Mayr Bros.' Proposal}

\begin{tabular}{|c|c|c|}
\hline \multicolumn{2}{|l|}{ III Cover Sheet } & \\
\hline \multicolumn{3}{|l|}{ i. Profesal } \\
\hline Project Tile: & Cares: & Excluate: \\
\hline Technologes: & $y_{\text {es }}$ & No \\
\hline Lasrall Adivowole Sond Prive & 四 & $\Xi$ \\
\hline Inrall Pmarammabis Loric Cootrollen & 目 & $\Xi$ \\
\hline 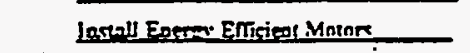 & 囚 & $\square$ \\
\hline $\begin{array}{l}\text { Confidential or Proprietary } \\
\text { Mayr Bros. Logging produ }\end{array}$ & $\begin{array}{l}\text { ion: } 囚 \\
\text { is prop }\end{array}$ & 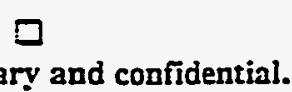 \\
\hline
\end{tabular}

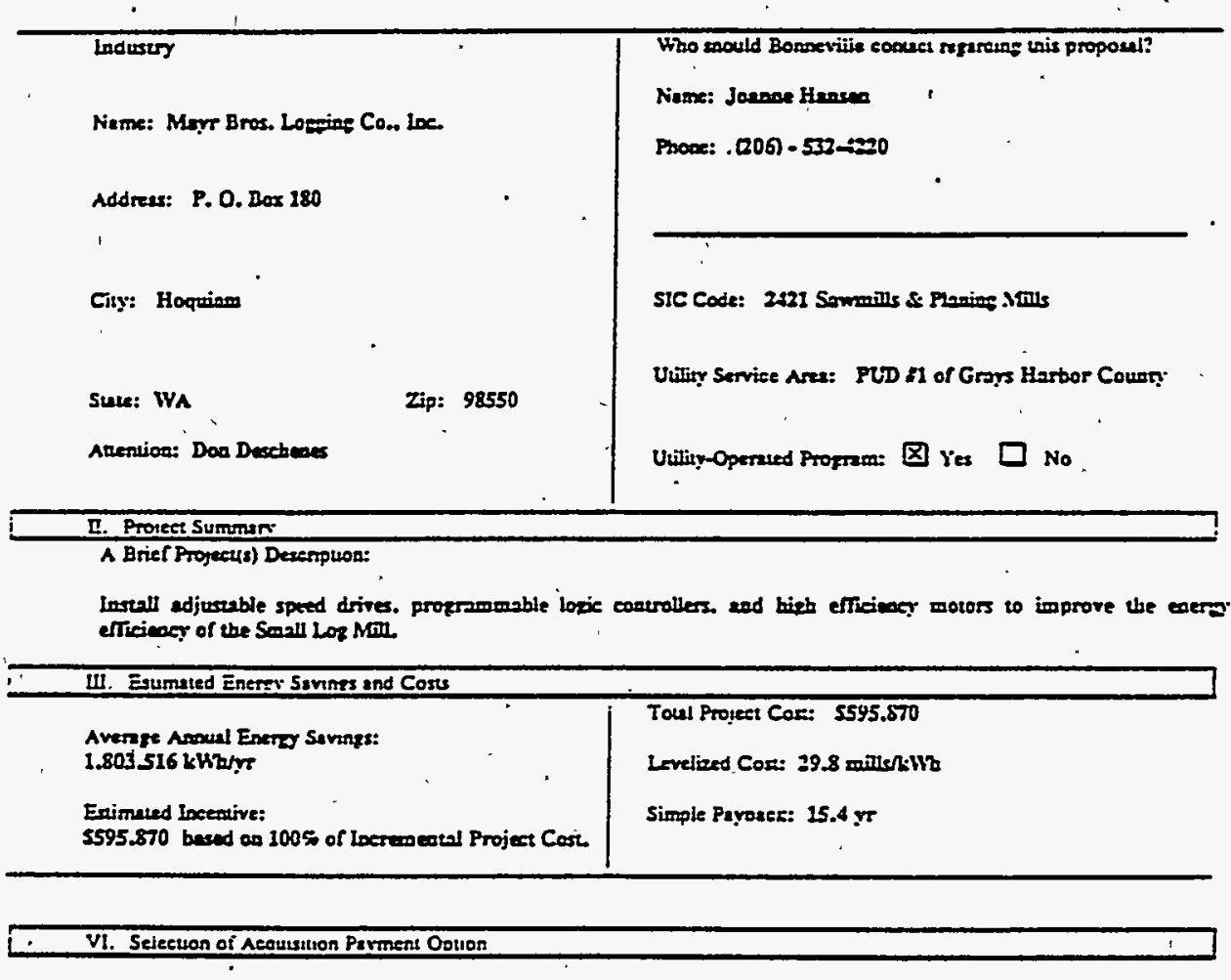

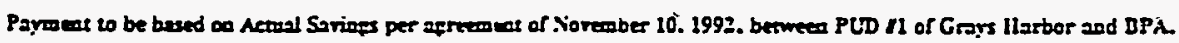

$\boldsymbol{\Psi}$

DKACO Enerzy Senices

$+$

\section{B.1}


Appendix C

Project Cost Estimates 


\section{Appendix C}

\section{Project Cost Estimates}

The total cost of installing the energy conservation measures in the small log mill is subjective because equipment installation contractor invoices did not always segregate costs associated with the energy conservation measures from costs associated with other aspects of constructing the small log mill. An itemized listing of project costs presented in the completion report is compared to estimates prepared by Bonneville and PNL in Table C.1. The Bonneville and PNL estimates were based on independent reviews by these two organizations of project cost data presented in the completion report.

The Bonneville estimate differs from the completion report due to exclusion of part of the installation costs invoiced by Campbell Electric. PNL's review of the Campbell Electric invoices yielded a slightly lower figure than Bonneville's. In addition, PNL's review of completion report data regarding the incremental cost of upgrading to high-efficiency motors yielded a slightly lower figure. Finally, charges for interest during construction were excluded by PNL to be consistent with costs documented for other E\$P projects, which are also reported on an "overnight construction" basis. Charges for interest during construction are captured in the financial methodology used to calculate levelized energy costs.

Table C.1. Project Cost Comparison

\begin{tabular}{||l|c|r|r||}
\hline \multicolumn{1}{|c|}{ Item } & Completion Report & Bonneville & \multicolumn{1}{c|}{ PNL } \\
\hline Engineering, Project Management, & 88,200 & 88,200 & 88,200 \\
$\quad$ and Proposal Preparation & & & \\
Equipment Procurement & 332,548 & 332,548 & 332,548 \\
Anderson Controls & 7,943 & 7,943 & 6,006 \\
High-Efficiency Motor Upgrade & 41,467 & 41,467 & 41,467 \\
GE Supply & & & \\
Equipment Installation & 187,736 & 65,073 & 62,578 \\
Campbell Electric & 104,975 & 104,975 & 104,975 \\
Mayr Bros. & 7,025 & 7,025 & 7,025 \\
Metering & 8,300 & 8,300 & 8,300 \\
Completion Report Preparation & 47,317 & 47,317 & 0 \\
Interest During Construction & $\$ 825,511$ & $\$ 702,848$ & $\$ 651,099$ \\
Total & & & \\
\hline
\end{tabular}

C.1 